\title{
Tüketicilerin sinik davranışlarının netnografya ile tespiti
}

\author{
Detection of consumers' cynical behaviors with \\ netnography
}

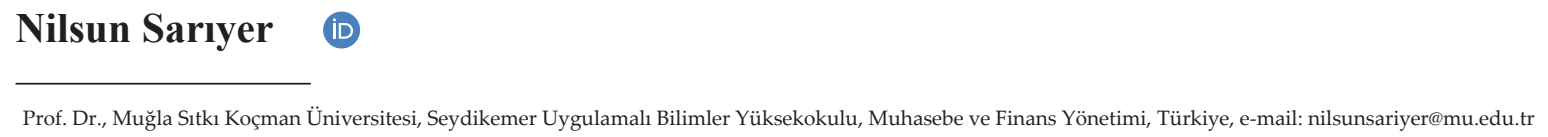

Öz

Tüketici sinizmi, tüketicilerin işletmeye karşı takındı̆̆ı olumsuz davranışlar olarak tanımlanmaktadır. Bu davranışların temelinde işletmelerin menfaatleri için tüketicilere zarar verdiklerine olan inanç yatmaktadır. Bundan dolayı tüketiciler işletmeye karşı olumsuz bir tutum geliştirmektedirler. Bu çalışmada bu tüketicilerin davranışları ele alınmıştır. Sinik tüketiciler nasıl davranır? sorusunun cevabını bulmak amacıyla nitel araştırma yöntemlerinden netnografya kullanılmıştır. $\mathrm{Bu}$ amaçla araştırmacı, tüketicilerin internet ortamında sinik tutumlarını ifade ettikleri web şikayet sitelerini iki ay boyunca takip etmiştir. Günlük şikâyet sayılarının fazlalığı gözönüne alınarak şikâyet sitelerinden biri tercih edilmiştir. Ancak şikâyetlerin farklı konular içerdiği de gözlemlenmiştir. Bu nedenle araştırma kargo şirketleri ile sınırlandırılmıştır. Veriler toplanırken araştırmacı, seçilen web sitesinde katılımsız gözlemci olarak yer almıştır. Tüketicilerin şikâyetleri beş ay boyunca (15 Mart 2021 ila 15 Ağustos 2021) kaydedilmiştir. Toplam 564 şikâyet metni elde edilmiştir. Veriler, arşivsel veri olarak toplanmış ve Atlas.ti nitel analiz programı aracılığ $\breve{1}_{1}$ le değerlendirilmiştir. Verilerin yorumlanmasında ise tematik analiz yöntemi kullanılmıştır. Analiz sonucunda elde edilen bilgilerin literatürle uyumlu olduğu ortaya çıkmıştır. Tüketicilerin üç sinik davranış gösterdikleri sonucuna ulaşılmıştır: Bilişsel Sinizm, Davranışsal Sinizm ve Duygusal Sinizm. Bilişsel sinizm davranışının güvensizlik, zorlama (tehdit) ve haksızlık durumlarında; davranışsal sinizm davranışının şikâyet, pişmanlık, aldatılmak ve mağdur olma durumlarında ve duygusal sinizm davranışının şüphe, boş vaat, haksızlık ve mağdur olma durumlarında geliştiği bulgulanmıştır.

Anahtar kelimeler: Tüketici sinizm, tüketici tatminsizliği, netnografya.

JEL kodları: M31, M30

\begin{abstract}
Consumer cynicism is defined as the negative behaviors of consumers towards the business. The basis of these behaviors is the belief that they harm consumers for the benefit of businesses. Therefore, consumers develop a negative attitude towards the business. In this study, the behaviors of these consumers are discussed. How do cynical consumers behave? Netnography, one of the qualitative research methods, was used to find the answer to the question. For this purpose, the
\end{abstract}

Citation/Atıf: SARIYER, N., (2021). Tüketicilerin sinik davranışlarının netnografya ile tespiti. Journal of Life Economics. 8(4): 485-497 DOI: 10.15637/jlecon.8.4.08

Corresponding Author/ Sorumlu Yazar: Nilsun Sariyer

E-mail: nilsunsariyer@mu.edu.tr, sariyernilsun@hotmail.com
Bu derginin içeriği Creative Commons Attribution-NonCommercial 4.0 Uluslararası Lisansı altında lisanslanmıştır. Content of this journal is licensed under a Creative Commons Attribution-NonCommercial 4.0 International License. 
researcher followed the web complaint sites where consumers expressed their cynical attitudes on the internet for two months. Considering the high number of daily complaints, one of the complaint sites was preferred. However, it has been observed that the complaints include different issues. For this reason, the research is limited to cargo companies. While collecting the data, the researcher took part in the selected website as an unattended observer. Consumer complaints were registered for five months (from March 15, 2021 to August 15, 2021). A total of 564 complaint texts were obtained. The data were collected as archival data and evaluated through the Atlas.ti qualitative analysis program. Thematic analysis method was used in the interpretation of the data. As a result of the analysis, it was found that the information obtained was compatible with the literature. It was concluded that consumers show three cynical behaviors: Cognitive Cynicism, Behavioral Cynicism and Emotional Cynicism. It has been found that cognitive cynicism behavior develops in situations of distrust, coercion (threat) and injustice, behavioral cynicism behavior develops in cases of complaint, regret, being deceived and victimized, and emotional cynicism behavior develops in cases of doubt, empty promise, injustice and victimization.

Keywords: Consumer cynicism, consumer dissatisfaction, netnography.

JEL codes: M31, M30.

\section{GİRIŞ}

Son otuz yıldır Müşteri İlişkileri Yönetimine ağırlık veren işletmeler, teknoloji ve haberleşme alanındaki yeniliklerin kullanımını ile müşterileriyle daha etkin iletişim kurarken müşteri değeri yaratmayı da hedeflemektedirler. Yeni ve mevcut müşterilerini elde tutmaya ve bu müşterilere üst model, çapraz ürün gibi farklı alternatiflerle daha fazla satış yapmaya çalışmaktadırlar. Bu çabalara rağmen memnuniyetsiz müşteriler mevcuttur. Başka bir ifadeyle her zaman tatmin olmamış, işletmeyi terk eden, ürüne, markaya ya da işletmeye yabancılaşan müşteri grupları vardır. $\mathrm{Bu}$ müşterilerin bir kısmı yaşadıkları olumsuzlukları etraflarına anlatmakta hatta markalara savaş açmaktadırlar. Bazıları ise sessiz kalmayı tercih etmektedirler. $\mathrm{Bu}$ çalışmada olumsuzlukla karşılaşan tüketicilerin geliştirdikleri tutumlardan biri olan "tüketici sinizm" kavramı ele alınmıştır. Yaşanan olumsuzluklar, kötü tecrübeler, işletmeye güvensizlik, şüphe, tatminsizlik gibi birçok şekilde ortaya çıkan tüketici sinizm kavramı, son dönemlerde tüketici davranışları açısından ön plana çıkmaya başlamıştır. Çünkü işletmelerin devamlılıklarını sürdürmeleri sadık ve mevcut müşterilerine bağlıdır. Günümüz şartlarında ise müşterilerin rakiplere kayması oldukça kolaydır. Özellikle sunulan birçok alternatif ve yeni özellikler müşteriyi cezbetmektedir. Bu durumda işletmelerin sadık müşterileri ve mevcut müşterilerini daha çok tatmin etmeleri gerekmektedir. Bununla birlikte tüketim tecrübesi sonucunda herhangi bir olumsuzluk yaşayan tüketiciyi kaybetmeyi göze almak istemezler. İşte bu nedenle sinik tüketici nasıl davranır? sorusunun cevabı önemlidir. Bu çalışmada öncelikle sinizm ve tüketici sinizm kavramları incelenmiş daha sonra sinik tüketici davranışını irdeleyen netnografik bir araştırma yapılmıştır.

\section{SİNizM}

Bireyin kendini toplumdan soyutlayarak idealist bir hayat yaşaması felsefesine dayanan sinizm kavramının ilk olarak M.Ö. 4. yy.'da Antik Yunan'da ortaya çıktığı düşünülmektedir (Andersson, 1996: 1397; Chylinski ve Chu; 2010: 798; Indibara ve Sanjeev, 2020: 78). Bilinen ilk sinik, Sokrates'in izinden giden Antisthenes'dir. Atina'lı Antisthenes (İ.Ö. 444-368), insanın tam bağımsızlık ve özgürlügünü savunan, erdeme ve mutluluğa böylelikle erişebileceğini ileri süren bir okul kurmuştur (Erdoğan ve Bedük, 2013: 19). Ancak sinizmin en önemli temsilcisi Antisthenes'in öğrencisi olan Diogenes olarak kabul edilmektedir (Dudley, 1937: 3). Dürüst bir insan bulmak için gün ışığında bile elinde fenerle gezdiği söylenen Diogenes'in kişiliği ve öğretisinin sinizme kesin şeklini verdiği öne sürülmektedir (Luck, 2011: 15).

Kavramın Yunanca köpek anlamina gelen "kyon"dan geldiği iddia edilmektedir (Aslan ve Şimşek, 2018: 117). Literatürde sinizm teriminin yanısıra kinisizm teriminin de kullanılması bu kökenden geldiğini doğrular niteliktedir (Tokgöz ve Y1lmaz, 2008: 443). Sinikler, fikirlerini bir havlama (bark) şeklinde söylerler ve davranışlarında saldırganlık vardır (Roberts, 2006: 4). Hatta Diogenes' in de kendisini "köpek" olarak tanımladığı ve bundan rahatsızlık duymadığı öne sürülmektedir (Kennedy, 2017: 42). Bu felsefeyi benimseyenler, Antik Çă̆ sonrasında da var olmuşlardır. Mesela, Montaigne (1580) "Denemeler" adl eserinde Antisthenes ve Diogenes'den defalarca bahsederek sinizme atıfta bulunmuştur (Laursen, 2009: 473-474). Bununla birlikte 19. yüzyılın başlarından itibaren kavramın kullanımının değişerek olumsuzluk içermeye başlad1ğ1 görülmektedir (Mazella, 2007: 182; Luck, 2011: 1819). Erdemli yaşamı ilke edinen, kanaatkâr yaşam tarzına ve nispeten iyimser olan antik dönem siniklerinin aksine günümüz sinikleri, kötümser ve güvensiz bir 
bakış açısına sahiptirler (Mantere ve Mantinsuo, 2001: 5). Başka bir ifadeyle başlangıçta kendini toplumdan soyutlama ve idealist bir hayat yaşama şeklinde bir ekolü ifade eden sinizm, günümüzde güven kaybı ve bunun getirdiği olumsuz tutumlarla ilişkilendirilmektedir (Güven, 2016: 155).

Literatürde sinizm, bir kişilik özelliği ya da tutum olarak nitelendirilmiştir. Sinizmi, doğuştan gelen ve bireyin yaşamı boyunca istikrar gösteren olumsuz kişilik özelliği olarak nitelendiren birçok bilim insanı bulunmaktadır (Abraham, 2000: 271). Zaman içinde bu yaklaşım reddedilerek sinizmin deneyimlere dayanan ve değişim gösterebilen öğrenilmiş bir tutum olduğu konusunda fikir birliğine varılmıştır (Andersson, 1996: 1400; Chylinski ve Chu, 2010: 801). Bundan dolayı bireylerin yalnız kendi çıkarlarını gözettiğine inanan ve herkesi çıkarcı gören kimseye sinik, bu görüşü açıklamaya çalışan düşünceye de sinizm denilmektedir (Erdoğan ve Bedük, 2013: 19). Sinizm, insanların diğer insanlardan hoşlanmaması, otorite ve kurumlara karşı olumsuz ve güvensiz tutumlara sahip olması, engellenme, umutsuzluk ve hayal kırıklığı, kişi, grup, ideoloji, toplumsal gelenek veya kurumlara karşı negatif duygular duyma ve güvensizlik, insanın niyet ve faaliyetlerinin iyilik ve samimiyetine karşı çıkma eğilimi (Arslan, 2012: 13); insanların inanç ve davranışlarına güvenmeme anlayışı (Luck, 2011: 15); insan doğasındaki bencilliğe yönelik bir inanç doğrultusunda başka kişilerin motivasyon araçlarını küçümseyici davranışlar (Costa vd., 1983: 929); sinirlenmeye açık olma, gücenme ve güvensizlik duygularının bir kombinasyonu (Güven, 2016: 154); insanların beklentileri karşılanmadığında hayal kırıklığına uğramaları bunun sonucunda kendisinin küçümsendiği, aldatıldı ̆̆ ması (Kanter ve Mirvis, 1989: 3); bir insanın, ideolojinin veya kurumun yaşatmış olduğu hayal kırıklığı, ümitsizlik ve güvenmeme şeklinde karakterize edilen bir tutum (Andersson, 1996: 1401; Atılgan vd., 2017: 37); bir bireye, gruba, ideolojiye, toplumsal düzene veya kuruma duyulan aşağılama ve güvensizliğin yanısıra hüsran, ümitsizlik ve hayal kırıklığıyla karakterize edilen genel ve özel bir tutum (Andersson, 1996: 1397-1398); bireylerin, işletmelerin veya diğer kurumların dürüstlükten yoksun oldukları ve amaçlarına ulaşmak için diğer insanları aldatmaktan veya manipüle etmekten çekinmeyecekleri inancına dayanan ve olumsuz duygularla (acl, öfke, kızgınlık vb.) karakterize edilen öğrenilmiş bir tutum (Dean vd., 1998: 345); bireylerin amaçları, sadakati ve iyi niyetinden şüphe duyma (Kanter ve Wortzel, 1985: 8) olarak tanımlanabilir. Birbirinden farklı bu tanımlar dikkate alındığında sinizmin öğrenilmiş bir tutum olduğu ve olumsuzluk içerdiği söylenebilir. Hatta bu olumsuzluk o kadar ileri düzeydedir ki; insanların kaybolmuş inanç durumu sözkonusudur (Chaloupka, 1999: 9). Bu durumuyla sinizm, bireyin dürüstlük, adalet ve sadakat prensipleri içinde oluşturduğu tüm inanışlarını kendi kişisel ilgilerine feda etmesidir (Abraham, 2000: 8). Literatürde sinizm kavramı, örgütsel sinizm, kişilik sinizm, kurumsal sinizm gibi farklı şekillerde ele alınmıştır. Pazarlamada ise tüketici sinizm olarak kullanılmaktadir.

\section{TÜKETICI SINİZM}

Chylinski and Chu (2010), tüketici sinizmini işletmelerin açık etmedikleri menfaatlerine yönelik niyetlerinden kaynaklanan faaliyetlerden dolayı zarar gören tüketicinin işletme ya da pazara karşı sergilediği tutumlar olarak tanımlamaktadırlar. Benzer tanımı, Helm vd. (2015) de yapmıştır. Onlara göre tüketici sinizm, işletmelerin fırsatçılıkları nedeniyle oluşan aynı zamanda tüketicilere zarar veren bir pazarın varlığını algılayan tüketicilerin oluşturdukları ve öğrendikleri tutumlardır (Helm vd., 2015: 518). Mikkonen vd. (2011), tüketici sinizmini din, politika, kültürel değerler gibi olguların eleştirilmesini içermesi nedeniyle tüketici eleştiriciliğinin daha radikal bir türü olarak düşünülmesi gerektiğini savunmuşlardır. Odou ve Pechpeyrou (2011), tüketici sinizminin tüketicilerin kendi varlıkları üzerindeki kontrolü yeniden kazanmaları olarak ifade ederken tüketim toplumu oluşturmak için dayatılan tüketim kodunu deşifre etmeye yönelik ikna çabalarından bahsederler. Yazarlar, Cherrier ve Murray (2004) tarafından "pazarlamanın gizli yüzü" olarak ifade edilen kavrama karşı oluşturulan manipülasyon olarak tüketici sinizmi kavramına dikkat çekmektedirler (Odou ve Pechpeyrou, 2011: 1800). Yine Mikkonen vd. (2011) tüketici sinizmini piyasa veya piyasadaki kurumlara karşı oluşan şüphe, hayal kırıklığı ve aldatılmanın farkına varılmasına yol açan psikolojik telafi stratejisi olarak tarif etmektedirler.

Andersson (1996), Dean vd. (1998) ve Stanley vd. (2005) gibi sosyal bilimlerdeki sinizm ile ilgili çalışmaları dikkate alan Chylinski ve Chu (2010), tüketici sinizmini bilişsel, duygusal ve davranışsal bileşenlerden oluşan bir süreç olarak değerlendirmişlerdir. $\mathrm{Bu}$ süreç şöyle gelişmektedir. Öncelikle tüketicilerin amaç ve değerleri ile işletmenin amaç ve değerleri arasindaki uyuşmazlık tatminsizliğe yol açmakta daha sonrasında tatminsizliğin tekrarlanması tüketicilerde işletmenin kendi çıkarlarına hizmet ettiği güdülerin olduğu düşüncesini ortaya çıkartmakta ve son olarak gerçekleşmeyen vaatlerden şüphe duymaya ilişkin baskın bir inanç oluşturmaktadır (Chylinski ve Chu, 2010: 805). Tüketici, bu inancin sonucunda sinizme yönelik tutum oluşturmaktadır. Hatta Göktaş (2019)'a göre tüketici satın aldığı markalardan sürekli şüphe etmekte aynı zamanda kandırıldığını ve güven duymaması gerektiği düşüncesine her zaman sahiptir. Böylece ortaya marka düşmanı bir tüketici kesimi çıkmaktadır. Bu tarz tüketicilere sinik tüketici ve bu akıma da tüketici sinizmi denmektedir (Göktaş, 2019: 
1652).

Literatürde genellikle güvensizlik, karamsarlık ve aşağllama gibi duygularla karakterize edilen ve olumsuz bir güç olarak görülen tüketici sinizmini farklı perspektiften değerlendiren Mikkonen vd. (2011), pazarlama kurumları tarafından tüketicilere sunulan normalize edilmiş öznellik biçimlerine karşı tüketici direnişi ve toplumsal eleştiri biçimine tüketici sinizm demişlerdir. Bu açıdan tüketici sinizmi, dönüştürücü etkiler yaratmak için özellikle retorik saldırının kullanımına dayanmaktadır (Mikkonen vd., 2011: 111). Reklam, halkla ilişkiler gibi pazarlama iletişiminde kullanılan birçok mesajdan etkilenerek ürün satın alan tüketicinin beklentileri karşılanmadığında bu saldırılar ortaya çıkmaktadır. Diğer müşterilerin benzer olumsuz söylemleri, olumsuz ağızdan ağıza iletişim, fısıltı ya da vizıltı söylemleri bu saldırıları daha da şiddetlendirmektedir. Hatta günümüzde sosyal medya ve dijital iletişim araçlarının retorik saldırıları arttırdığına inanılmaktadır.

Tüketici sinizmi, tüketicinin işletmeye karşı takınd1ğ1 olumsuz davranışlardır. Bu davranışların ortaya çıkma nedeni, işletmelerin tüketicilere zarar verecek gizli niyetlerinin olmasıdır (Chylinski ve Chu, 2010: 805; Odou ve Pechpeyrou, 2011: 1802). Bahsedilen bu niyetler, işletmenin tüketicilerin istek ve ihtiyaçlarına neredeyse hiç ilgi duymaması bunun yerine kendi ç1karlarını ya da menfaatlerini kollaması olarak ifade edilmektedir (Dolen vd., 2012: 306). Bu nedenle tüketici sinizminde "işletmelerin çıkarcılığı" inancına odaklanılmaktadır. Başka bir deyişle kavramın merkezinde işletmelerin kendi menfaatleri ya da fırsatçıllk yapmaları nedeniyle "tüketicilerin zarar görmesi" yer almaktadır. Özellikle markaların tüketici yararına katkı sağlamadığı, tüketicilerin iyi niyetlerini suiistimal ettiği ve bunlardan dolayı tüketici memnuniyetsizliğin oluştuğu ve arttığı gözlenmektedir (Amezcua ve Quintanilla, 2016: 291). Helm vd. (2015), tüketicilerin sinik duygulara sahip olma nedenlerini işletmelerin üç davranışına bağlamaktadırlar. Bunlar; genel fırsatçılık, tüketicilere yönelik fırsatçılık ve aldatmadır (Helm vd., 2015: 520). Genel firsatçılık, işletmelerin tüm değerleri (etik değerler gibi) dikkate almaksızın sadece kendi çıkarları peşinde koşmaları olarak ifade edilmiştir. Mesela, yüksek satış oranları, pazarda lider olma, küçük rakipleri ortadan kaldırma gibi. Tüketicilere yönelik fırsatçılık, işletmelerin kendi müşterileri de dâhil olmak üzere kendi çıkarları dışındaki tüm paydaşları gözardı etmeleridir. Müşteri hizmeti, müşteri şikâyetini çözme gibi müşteriye yönelik işletmeye ek maliyet getirecek hiçbir hizmetin eklenmemesi tüketicilere yönelik fırsatçılık olarak söylenebilir. Aldatma ise farklı pazarlama faaliyetleriyle tüketiciyi aldatmaya yönelik fırsatçılık türleridir. Özellikle pazarlama iletişimi mecralarında yer alan vaatlerin gerçekte olmaması ya da abartılması gibi.
Sinizm kültürü, tüketicileri ürün ve fiyatları konusunda şüphe duymalarına, karşılaştırma yapmalarına hatta fayda ve maliyet dengesini daha fazla sorgulamalarına neden olmaktadır. Sinik tüketicilere göre kendileri markaların avıdır (Berdysheva ve Romanova, 2017: 400). Bu nedenle tüketici sinizmini psikolojik bir strateji olarak değerlendirilmesinden bahsedilmelidir (Mikkonen vd., 2011: 101). Yani; tüketiciler pazar ve pazardaki işletmelere karşı şüphe, hayal kırıklığı ve kandırılma hissi yaratan bir strateji geliştirirler. Bu strateji bir tür psikolojik telafi stratejisidir (Mikkonen vd., 2011: 101; Güven, 2016: 157). Çünkü tüketiciler olumsuzluklara karşı savunma mekanizmalarını çaliştırarak sinizm olgusunu geliştirmektedirler. $\mathrm{Bu}$ olgunun gelişme nedenlerinin başında siniklerin yaşam tarzları gelmektedir. Sinikler, erdemli yaşamı temel amaç ve mutluluğun tek koşulu olarak görürler. Hatta çoğu sinik için "erdemli yaşamak" ile "mutlu yaşamak" aynı anlamdadır. Siniklere göre, erdem disiplinli ve sıkı çalışarak kazanılmakta ve benimsendiği takdirde asla yok olmamaktadır. Erdemli insan "bilge"; erdemli olmayan ise "ahmak" olarak nitelendirmektedirler (Luck, 2011: 30). Hatta bilgeliği en yüce erdem olarak gören sinikler, toplumun değerleri, normları ve geleneklerini de sorgulayarak acımasızca eleştirmişlerdir (Mantere ve Mantinsuo, 2001: 4). Bu nedenle sinizm ile karşılaştıklarında buna tahammül edemeyerek diğer tüketiciler arasında bunu hızla yayarak geleceğe ilişkin güvenilir davranış beklentisi içine girmek isteyeceklerdir. Bu, pazar davranışlarını olumsuz yönde etkileyerek işletme ya da marka imajını zedelenmekte ve uzun dönemde finansal açıdan ciddi kayıplar yaşanmasına yol açmaktadır. Bu durum işletmenin varlığını sürdürmesini de güçleşmektedir (Akçay, 2021: 27).

Naletelich ve Ketron (2017), tüketici sinizmini tüketicilerin kendilerini koruma amaçlı ve saf olmadıklarını gösterme çabaları olarak tanımlamaktadır. Sinikler, pazarlama tekniklerine direnmenin yanısıra zorunlu tüketim ürünlerinin pazarlanması da dâhil herşeye şüphe ile yaklaşırlar. Siniklere göre ahlaki ilkelerini bir kenara bırakan işletme yöneticileri, performans hedeflerine ulaşmak amaciyla (Kanter ve Mirvis: 1989) tüketicileri istismar etmekten kaçınmazlar (Kretz, 2010: 394). Sinik tüketicilerin birçoğu aldatıldığı algısına sahiptir hatta aldatıldıkları konusunda ön yargıları da mevcuttur. Bu tüketiciler ürünlerden şüphe etmenin ötesinde diğer tüketicileri olumsuz yönde etkilerler. Bununla birlikte tüketiciler satın alacakları markalarla ilgili önceden aldatıcı olduğuna dair bilgiye erişmişlerse, sinik davranma düzeylerini artt1racaklardır. Bunun tam tersi, işletmenin dürüst ya da güvenilir olduğu bilgisi varsa ya da tüketiciye karşı bu şekilde davranış sergilenmişse tüketicilerin aldatılma düşüncesi ve sinik davranma düzeyi düşecektir (Ketron, 2016, 33-34). Bu nedenle işletmelerin dürüstlük ve güvenilirlik konularına yönelmesi önemlidir. 
Tüketici sinizmi negatif bir kavramdır. Bu kavram, kişi, kurum ya da işletmenin dürüst, bencil ve sadece kendini düşündüğü inanışını yansıtır. Bundan dolayı sinik bir tüketici, kendini bu negatiflikten korumak için geri çekilme ve uzaklaşma hareketi sergilemektedir (Dolen vd, 2012: 308). S1klıkla tüketicilerin işletmelerle olan ilişkilerinde kızgınlık duydukları, tatminsizlikleri konusunda işletmeye tepki hissi içinde oldukları, beğenmediklerini boykot ettikleri ya da diğer insanları bu işletmelerden alışveriş yapmamalar1 konusunda uyardıklarına şahit olunmaktadır (Laczniak vd., 2001: 69). Sinik tüketiciler; tüketicileri (sadece aktivistleri değil aynı zamanda sıradan tüketicileri de) bir piyasa sisteminin oyuncuları olarak görürler ve sosyal olarak bilinçli seçimler yapma sorumluluğuna sahip olmaları konusunda uyarırlar (Helm vd. 2015: 515). Bunları gözönüne alan birçok tüketici satın alma eyleminde bulunmazlar. Hatta kurumsal sosyal sorumluluk uygulamalarına ilişkin gönüllülük veya mali yardım gibi desteklerden de vazgeçerler (Ogunfowora vd., 2015: 1310).

Aslında sinik müşteriler, işletmelere güvenmek isterler. Mesela, fiyatın şeffaf olmadığı zaman sinik davranış eğilimi gösterebilirler genellikle ürünü de boykot etmeyi tercih ederler. Buna karşın fiyat konusunda gerekli şeffaflık oluşturulursa ayrıca fiyat prosedürlerinin adil olduğuna inanılırsa sinizmin düzeyi düşebilir, bunun sonucu olarak tüketicilerin satın alma niyeti de olumluya çevrilebilir (Atılgan vd., 2017: 41). Bununla birlikte sinik tüketicilerin birçoğu acı duymakta ve kızgın görünmektedirler. İşletmelere karşı isyan etmektedirler. Beğenmedikleri işletmeleri veya markaları boykot ederek etrafındakileri de bu davranışı göstermeye yönlendirmektedirler (Chylinski ve Chu, 2010: 796). Hatta ileri düzeyde tüketici sinizmi yaşayan bireyler, işletmelerin imajlarını zayıflatmak, bu işletmeleri kötü olarak etiketlemek ve tüketicileri boykot etmeye teşvik etmek amacıyla insanlara yalan söylemekte ve gerçekçi olmayan fikirleri bile yayabilmektedirler (Amezcua ve Quintanilla, 2016: 292). Tüm bunlar gözönüne alınarak bu çalışmada sinik tüketici davranışı ele alınmıştır. Sinik tüketici davranışı nedir? sorusuna cevap aranmıştır.

\section{TASARIM VE YÖNTEM}

Araştırmada nitel araştırma yöntemlerinden netnografya kullanılmıştır. Çevrimiçi etkileşimlerle derinlemesine insan anlayışı kazandıran kültürel yansımalar olarak görülen netnografya, çevrimiçi topluluklarda giderek daha fazla sosyalleşen günümüz tüketicisini anlamak adına sanal topluluklardaki tüketici davranışını inceleyen bir yöntemdir (Kozinets, 2010). Aslında netnografya, etnografik analizin sanal ortam üzerinden yapılması olarak ifade edilebilir (Akturan, 2009: 3; Kozinets, 2002). "Sanal etnografi", "siber etnografi" gibi terimlerle de anılan netnografi özellikle pazar- lama alanında, tüketici davranışlarını analiz etmede bir yöntem olarak kullanılmaktadır. Araştırma konusunun tüketici sinizm olması nedeniyle netnografya tercih edilmiştir. Çünkü tüketiciye dış müdahale olmadan davranışını ortaya çıkartmak hedeflenmiştir. Kozinets (2006), netnografyanın araştırmacıya "görünmezlik elbisesi” giydirdiğini ifade etmektedir. Böylece tüketici rahatsız edilmeden inceleme ve veri toplama imkânına sahip olunmaktadır. Bu araştırmada da bu nedenlerle netnografya kullanılmıştır.

Araştırmanın literatür kısmında da anlatıldığı gibi tüketici sinizm bir tutum olarak ele alınmaktadır. Tutum, bir nesne, bir kişi veya kişiler dâhil bir konu, fikir veya bir nesne hakkındaki olumlu, olumsuz veya ilgilenmeme yönündeki değerlendirmeler ve bu değerlendirmelere göre belirli şekilde davranma eğilimidir (Koç, 2013: 272). Bu tanım dikkate alınarak tüketicilerin tutum oluşturdukları ve bunu ifade ettikleri müşteri şikâyetleri ele alınmıştır. Ancak Kozinets (2002)'in ifade ettiği gibi çalışma için elverişli ortamın saptanması kimi zaman aylarca sürebilmekte ayrıca bu süreçte topluluklardaki katılımcı profillerinin ve tartışma konularının derinlemesine incelenmesi gerekmektedir (Kozinets, 2002: 63). Buna ilave olarak araştırmacının katılımcılarla iletişime geçmeden önce belirlenen topluluğun diline hâkim olması için "pusuya yatması" gerekmektedir (Maclaren ve Catterall, 2002: 323). Zira araştırmanın yürütüleceği ortama karar vermek için bazı hususlara dikkat etmek gerekmektedir. Mesela, topluluğun odaklı bir konu, grup veya bölüğe sahip olması, yüksek girdi trafiği sağlıyor olması, yeterli miktarda ileti içermesi, detaylı, açıklayıcı ve zengin veri sunması ve üyeler arası aktif etkileşime olanak veriyor olmasına dikkat edilmesi gibi (Kozinets, 2002: 63). Bunlar dikkate alınarak web siteleri araştırılmıştır. Müşteri şikâyeti ile ilgili sayfaların tüketici sinizm de içerdiği görülmüştür. Beklentileri karşılanmamış ya da bir şekilde olumsuz durumla karşılaşan tüketici, bu sayfalarda şikâyetini dile getirerek çözüm bulunmasını amaçlamaktadırlar. Aynı zamanda bu şikâyetlerde sinik tutumlarını da ifade etmektedirler. Bu amaçla araştırmacı, sinik tüketici davranışı olabilecek web sitelerini iki ay boyunca takip etmiştir. Bu inceleme sonucunda günlük şikâyet sayılarının fazlalığını da dikkate alarak araştırmanın daha sağlıklı yapılabilmesi için "bir müşteri şikâyet web sitesi®" seçilmiştir. Bu araştırmanın sınırıdır. Seçilen şikâyet sayfası, konuya uygunluğu, yüksek girdi sağlaması, yeterli düzeyde ileti içermesi, detaylı, açıklayıcı ve zengin veri sunması ve etkin şekilde çözümler sunması nedeniyle araştırmacı tarafından tercih edilmiştir.

Veriler toplanırken araştırmacı, seçilen web sitesinde katılımsız gözlemci olarak yer almış ve tüketicilerin şikâyetlerini beş ay boyunca (15 Mart 2021 ila 15 Ağustos 2021) takip etmiştir. Ancak günlük şikâyet sayısının fazlalığı ve şikâyet konularının farklılığı dik- 
kate alınarak şikâyetlerin temasının kargo şirketleri ile sınırlandırılmasına karar verilmiştir. Bu da araştırmanın diğer kısıtıdır. Toplanan bu veriler arşivsel veri olarak toplanmıştır. Arşivsel veri, çevrimiçi ortamda halihazırda var olan ve araştırmacının herhangi bir katılımı olmaksızın kopyalanarak elde edilen verilerden oluşmaktadır (Kozinets, 2010: 98). Şikâyet web sitesinde doğrudan şikâyetlerini paylaşan üyelerinin paylaşımlarına dayanarak arşivsel veriler oluşturulmuştur. Araştırma konusu ile ilgili aranan cevaplara yardımcı olabilecek 564 şikâyet metni elde edilmiştir. Bazı akademisyenler, çevrimiçi ortamın yapısı itibariyle üyelerin iletilerini kamuya açık kılmakta olduğunu fakat araştırmacının ulaşılabilen her veriyi çalışmasına dâhil etme hakkına sahip olmasını tartışmalı bir konu olarak gördüklerini ifade etmektedirler (Langer ve Beckman, 2005: 195; Beaven ve Laws, 2007: 131). Bu nedenle toplanan bu şikâyet metinlerindeki isim, üye ismi ya da takma isimler verilmemiştir. Ayrıca metinlerde yazım hataları, imla kuralları vb. herhangi bir düzeltme yapılmamıştır.

\section{BULGULAR}

Toplanan veriler, Atlas.ti nitel analiz programı aracılığ ile sinıflandırılarak tematik analiz yöntemi ile yorumlanmıştır. Bundan önce verilerin iç geçerliliğin sağlanması için bir başka akademisyenden toplanan verileri kontrol etmesi istenmiştir. Verilerin tutarlı olduğu ve anlamlı bir bütün oluşturduğu bu şekilde teyit edilmiştir. Zaman etkisini de ortadan kaldırabilmek için beş aylık süre içindeki verilerden yararlanılmıştır.

Tematik analiz gerçekleştirilirken ilk önce temalar belirlenmeye çalışılmıştır. Kodlama yapılırken literatür de dikkate alınarak temalar oluşturulmuş ve iki aşama şeklinde kodlama tamamlanmıştır (Braun ve Clarke, 2006: 82). İlk aşamada onbir adet tema belirlenmiş, daha sonra bu temalar birleştirme, bölme ve vazgeçme aşamalarından sonra dokuz adet temaya düşürülmüştür. Temalar isimlendirilirken temaların içeriklerine uygun olarak her birinin içerdiği kodları en iyi şekilde kapsaması hedeflenerek isimler belirlenmiştir. Bu çerçevede araştırmadan elde edilen bulgulara bakıldığında, üç ana tema ortaya çıkmıştır. Bu temalar belirlenirken Chylinski ve Chu (2010) ifade ettikleri tüketici sinizm ile ilgili boyutlar kullanılmıştır. Bunlar bilişsel, davranışsal ve duygusal olarak adlandırılmıştır. Bilişsel boyutunda şüphe, güvensizlik, kuşku ve itimatsızlık kavramlarına dikkat çekilirken, sinizmin duygusal boyutunda yabancılaşma ve tatminsizlik kavramları ele alınmaktadır. Davranışsal boyutunda ise direniş ve düşmanlık kavramlarından bahsedilmektedir (Chylinsky ve Chu, 2010:780). Aslında Dean vd. (1998) bunları örgütsel sinizm boyutları olarak isimlendirmişlerdir. Bu bilgiler de dikkate alınarak örgütsel sinizmdeki ifadeler tüketici sinizmine uyarlanmıştır.

\subsection{Bilișsel Sinizm}

Bilişsel sinizm, tüketicilerin işletmenin dürüstlükten yoksun olduğuna dair inancıdır (Erdoğan ve Bedük, 2013: 20). Tüketici sinizmin bilişsel boyutunda tüketiciler, işletmenin dürüstlük ve şeffaflıktan yoksun olduğu düşüncesiyle işletmelerin ilkelerinin olmadığına, iş ilişkilerinin ve etkileşimlerin işletmelerin menfaatlerine yönelik şekillendiğini düşünmektedirler. İşletmeler kendi menfaatleri doğrultusunda hareket etmekte; saygı, içtenlik ve güven gibi değerlerden ödün vererek ahlaki olmayan ve vicdan ile bağdaşmayan davranışlarla tüketicileri başbaşa bırakmaktadırlar (Ercan ve Kazançoğlu, 2019: 263). Örgütsel siniklerin düşünce şekline benzer şekilde sinik tüketiciler, satın aldıkları markaların yapmış olduğu satış tutundurma gibi faaliyetlerin adalet, dürüstlük ve samimiyet gibi birtakım ilkelerden yoksun olduğuna inanırlar (Erdoğan ve Bedük, 2013: 20).

Şikayet web sitesinden toplanarak netnografya ile analiz edilen şikâyet metinlerinde bilişsel sinizm ile ilgili bazı metinler şunlardır:

- Tüketici 1: İnternet sitesinden alışveriş yaptım kargo kodu:6270******17. A kargo ile tarafıma gönderilmiş fakat bu kargo bana teslim etmediği halde bana teslim ettiğini yazmış bu ne sorumsuzluktur iş bilmeyen kargolara ürün mü emanet ediyorsunuz? Güvenim tamamen sarsıldı kargomun derhal tarafıma teslimatını talep ediyorum bu konuyu çözmezseniz daha üst mercilere de şikâyet edeceğimden şüpheniz olmasın, sayg1lar...

- $\quad$ Tüketici 2: 14.07.2021 tarihinde saat 10.30 da dağ1tıma çıkartılan ürünlerim tarafıma teslim edilmediği halde sistemimizde teslim edildi yazıyor. XX şubesi ile en az 2 kez görüşmem oldu, evdeyim siparişim nerede bunun hesabını kim verecek nasıl bir kargo firması bu kimseye güven kalmadı.

- Tüketici 3:.....Ben bu kargoyu bekliyorum. YY şubesine ulaşmış gözüküyordu. Açıklamada da ilk teslimat tarihinde teslim edilecek yazıyordu. Bugün baktığımda "Adres Sorunu Nedeniyle Alıcıya Ulaşılamadı" yazıyor. Sizin bu şubeniz daha önce adresime teslimat yaptı hiç böyle sorun görmedim. Madem adres sorunu var telefon numaram yaziyor orada neden telefon edip sorunu ortadan kaldırmiyorsunuz?

- Tüketici 4: Tüketiciden tüketiciye satış uygulamasından sattı̆̆ım 2 adet 7 yaş çocuk şortunu ikiye katlayıp kargo poşetine koydum bantladım. Ürün karşı tarafa ulaşınca uygulama benden kargo farkı kestiğini bildirdi. 2 defa mail atmama rağmen uygulama bu dediler.....Bu uygulama devam ederse Bir çok insanın hakkına gireceksiniz. Büyük haksızlık oluyor. Umarım yorum ve 
şikâyetleri değer verirsiniz.

- Tüketici 5: Pazar günü internet alışverişi yaptığım alışverişte B kargo şirketini tercih ettim. Normalde 1 iş gününde geleceği yazıyordu. Yoğunluk vs. nedenlerle 1-2 gün gecikebileceğini düşünüp bekledim ancak bugün 4 iş günü oldu ve kargom hala elime ulaşmadi. Kargo takibinde 2 gündür dağıtıcıda olduğu görünüyor. ...... 1 siparişin 2 gündür neyini dağıtıyorsunuz anlamıyorum. Yarın da gelmezse bayram tatili girecek ve ben kitaplarıma ulaşamayacağım. Yaptığınız haksızlık. 1 iş gününde teslim edileceğini söylediğiniz bir siparişi böylesine geciktiremezsiniz. ZZ gibi severek alışveriş yaptığım bir şirketin de böylesine kalitesiz bir kargo firmasını neden ve nasıl tercih ettiğini anlayamıyorum. Siparişimin bugün içerisinde gelmesini talep ediyorum. Aksi halde gerekli yerlere şikayette bulunacağım.

- Tüketici 6: Ürünü teslim etmek yerine mesaj atıp gelip alın diyorlar! Tam bir rezalet.....Göründüğü kadarıyla C Kargo gibi bir marka ismi bu basit ve can sıkıcı problemi çözmüyor/çözemiyor! Basit sorular; 1. Kargo firmasının görevi nedir? 2. Kargo firması adrese gitmeden telefon açıp "gelin paketinizi alın yoksa 3 gün sonra geri gidecek" demesi ne anlama gelmektedir. Bu soruların cevabını sizden istemiyorum. Eğer kendinize cevap verebiliyorsanız sorularım amacına ulaşmış demektir. Ama şunu açı söylemeliyim ki; Bu şekilde devam ettiğiniz sürece de asla ama asla C Kargo'yu tercih etmeyeceğim. Ve hatta internetten bir ürün sipariş etmeden önce satıcının hangi kargo firmasıyla çalıştı̆̆ını soracağım. Eğer C Kargo ile gönderiyorlarsa onlardan alışveriş yapmayacağim.

- Tüketici 7: İnternet sitesinden 178 TL'lik alışveriş yaptım 150 TL üstü kargo bedava idi. Ürünler sitenin kendi sattığ ürünlerden. Ürünlerden birini kusurlu gönderdiler yakasında yağ lekesi var resmen iade etmek istediğimde kargo ücreti kesilmiş şekilde iade edeceklerini belirttiler ürünü hem kusurlu gönderiyorlar hem de kargo ücretini kesiyorlar ben kargo ödememek için ürün ekledim ama yaptıklarına bak pandemi dönemi hem iadeyle uğraşacağım artı bir de kusurlu gönderip paramı kesiyorlar. Gerçekten bu kadar müşterisini hiçe sayan bir firma görmedim.

\subsection{Davranışsal Sinizm}

Davranışsal sinizmde, tüketiciler sinizm duygusuna sahip olarak işletme ile ilgili şikâyette bulunma, dalga geçme ve eleştirme gibi davranışlar gösterirler. İşletmelerde, sinik davranışlar sözlü olmanın dışında genellikle eylemi gerektiren davranışlar olarak gözükmektedir (Brandes ve Das, 2006: 236; Karacaoğlu ve
İnce, 2012: 79). Bu boyutta, sinik tutum ve davranış sergileyenler, ürün ya da markanın geleceği hakkında kötümser ve iç karartıcı tahminler ortaya atarak olumlu olmayan davranışlarda bulunabilirler (Dean vd., 1998: 349). Mesela; boykot, şikâyet forumları oluşturmak gibi. Böylelikle hem kendilerini hem de diğer tüketicileri koruduklarını düşünürler. Bu tüketicilerin işletmeyi terk etme niyeti akıllarının bir köşesinde her zaman vardır (Beğenirbaş ve Turgut, 2014: 239; Ercan ve Kazançoğlu, 2019: 264).

Şikâyet web sitesinde davranışsal sinizm olarak nitelendirilen şikâyet metinlerinden bazıları aşağıdadır:

- Tüketici 8: D Kargo 2801*****44 takip numaralı ürünü kaybetti tabi inanırsam iade talep ettim 10 gün gelmeyince meğer ürün çoktan sahiplenilmiş ne gönderen ne alıcı ürünü bir daha alamadık. Para boşa gitti dava açmaya hazırlanıyorum 1 değil binlerce esnaf mağdur sadece bugün bana yarın başkasına.

- Tüketici 9: Kargo hakkında bilgi yazmıyor kargomun nerede olduğunu göremiyorum 5 gün oldu. Sipariş vereli pazartesi kargom hakkında bilgi verildi. Bir bilgi daha da bilgi verilmedi. Gönderi kodu 1103******18. E Kargo pişmanlık kaç gün oldu. Bir ürün bekliyorum.

- Tüketici 10: F firması kadar sorumsuz bir kargo şirketi görmedim. Müşteri hizmetlerine asla ulaşılmıyor.......Kargonuz Dağıtıma çıkarıldı mesajı geldikten tam üç gün sonra kargomu ulaştırdılar. Bu kadar sorumsuz bu kadar lakayıt bir şirket asla görmedim. Ürün aldığım WW şirketi derhal anlaşmaları kesilmeli.

- Tüketici 11: Kargo bana teslim edilmediği halde ilgili kargo şirketi yanıltan yeni bir firma. Her önüne gelen kargo firması açıp bildiğiniz milleti yanıltıyorlar. Teslim edildi olarak belirtip teslim etmiyorlar. Telefonları açan yok. Müşteri hizmetleri yok lütfen biri yardımcı olsun 3 hafta oldu neredeyse ürünüm ortada yok.

- $\quad$ Tüketici 12: XX marka 15 inch bilgisayarımı 2. El satış sitesi aracılığ ile 21.500 TL'ye anlaştığım kişiye ulaştırması amacıyla bir yakınıma G Kargo ile 21/01/2021 tarihinde gönderdim. Yakınımın doğum yapması nedeniyle paketin yakınımın adresine ekstra ücret ödeyerek teslim edilmesini talep ettim. Ancak bilgisayarıma talip olan kişi yakınımı kargo görevlisi gibi arayarak temassız teslimat kodunu öğrenerek Bahçeşehir şubesinden kimlik kontrolü bile yapılmadan bilgisayarı teslim alarak ortadan kaybolmuştur. Paket yakınıma teslim edilmemiş olmasına rağmen sisteme yakınıma teslim edilmiş gibi işlenmiştir. (Duruma dair kamera görüntüleri de elimde mevcuttur) ...... Şubenin güvenlik kriterlerini uygulamaması ne- 
deniyle bilgisayarımın bedeli olan 21.500 TL'nin tazmin edilmesi için kargo firmasına dilekçe yazdım ancak olumsuz sonuçlandı. Bu şikâyeti okuyan tüm duyarlı vatandaşlardan bir ricam olacak. Ben görme engelliyim ve bilgisayar telefon gibi cihazlar sizin gözünüz kadar benim için önemli. Bilgisayarımı müzisyen ve müzik bölümü öğrencisi olduğum için satıp daha uygun bir bilgisayar alarak geriye kalan parayla da enstrüman ihtiyaçlarımı karşılayacaktım, ancak şubenin zorunlu olarak yapması gereken kimlik kontrolünü yapmaması sebebiyle 21500 TL zarara girdim ve 4 aydır bu meseleyle uğraşıyorum. Üniversite son sınıf öğrencisiyim ve aynı zamanda yüksek lisans sinavlarına hazırlaniyorum. Ama bu sorumsuz F denen firma beni psikolojik ve maddi olarak çok zor durumda biraktı. Kargonun Karayolu Taşıma Yönetmeliğine uymadığı göz önünde bulundurularak zararımın karşılanması$\mathrm{n}$ talep ediyorum. Bilgisayarım olmadan çok zor idare etmeye çalışıyorum.

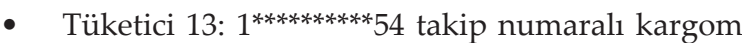
teslim edildiğine dair mesajım geldi. Şa. Te. isimli kişiye teslim edilmiş kayıtlarınızda bu şeklide. Fakat binada bu isimde oturan biri bulunmamaktadır. Mesaj 25.07.2021 tarihinde tarafıma geldi. Kargo bana teslim edilmedi. Apartmandan kimseye teslim edilmemiş. 5 gün sonra üst komşumun kapısına bırakıldığını öğreniyorum ve kargom açılmıştı. Ek işim gereği kargo firmalarıyla sürekli çalışma halindeyim fakat bir daha sizinle çalışmayı düşünmüyorum. Konu ile ilgili olarak sorumlu personelinizle ilgili inceleme ve soruşturmaya yapacağınızı düşünüyorum.

- Tüketici 14: İnternetten 15.07.2021 günü ürün sipariş ettim (G Kargo) 1042*****47 kargo takip numarası ile sürekli kontrol ettim. Kargom gelmeyince ayın 19 unda müşteri hizmetleri ile iletişime geçtim. 13:01 ve 13:16 saatlerinde iki görüşme yaptık. Kargonun bulunduğu şube sizi arayacak dediler. Ben de tamam dedim ve bekledim. Akşam saat 16:02 de arayan soran olmayınca tekrar müşteri hizmetlerini aradım. Kargo durumuna tekrar baktıklarında kargonun şubede olduğunu ama o gün dağıtıma çıkmadığını söylediler. Bayramdan sonrasında 24.07.2021 cumartesi günü tekrar dağıtıma çıkar alırsınız dediler. Bugün, yani ayın 24ünde müşteri hizmetlerini aradığımda (11:35 saatinde), kargonun 17.07.2021 günü dağıtıma çıktığını adres sorunundan dolayı teslim edilemediğini söylediler. Ben de birden fazla görüşme yaptığımı belirtince kargonun bulunduğu şube ile görüşeceklerini söylediler. Hatta beklediğimde bu sefer de bana telefon numaramin sistemde farklı olduğunu. Benzer ama yanlış yazıldığını belirttiler. Bu yüzden kargomu bana ulaştıramamışlar. Şimdi de 26.07.2021 pazartesi günü kargonun dağıtıma çıkarılacağını söylüyorlar. Ortada çok büyük bir ciddiyetsizlik var, müşterilerinize karşı tutarsız açıklamalarda bulunuyorsunuz ve bu noktada ben kargomu 1 haftay1 aşkın süredir beklerken mağdur kalıyorum.

- Tüketici 15: 29.05.2021 tarihinde Malatya'dan beklediğim kargom geldi. Gönderici bana kargolamadan önce paketli halini fotoğraf olarak gönderdi, gayet temiz ve güvenli bir paketleme idi. Ama bana gelen paketin ağzı yarıya kadar açıktı, ama tabi ki böyle bir şey yaşayacağım aklıma gelmediği için fotoğrafını çekmedim. Paketi tamamen açtım ve gelen bisikletin sağ tekeri k1rıktı. Dün bisikletçiye gösterdik tamamen tekerin değişmesi gerektiğini söyledi. Ben şu an çok mağdurum bir sürü masrafım çıktı, karşımda bir muhatap göremiyorum!

- Tüketici 16: WW işletmesine BES iptali başvurusunda bulundum. İptal evraklarını benimle alakasiz bir adrese I Kargo (158******84) ile göndermişler. I kargoda o adreste güya bana teslim etmiş. Teslim ederken kimlik sorma filan yok. Kime denk geldiyse artık vermişler. QQ işletmesinden gelen mesaj bu: (Sayin $\mathrm{AB}$, bireysel emeklilik sözleşmeniz 31.5.2021 tarihinde taraf1nıza teslim edilmiştir. Mersis No: $0434^{* * * * * * * * *} 19$ B002) ). Ama bana gelen evrak yok. Şu an evraklarım kimin elinde hiçbir bilgim yok...

- Tüketici 17: İ Kargo firması ZZ Şubesi ile her zaman yaşanan bir olay ne yazık ki. Evde olmama rağmen teslim edilemedi deniliyor. Sonrasında açıklama olarak alıcı şubeden teslim alacak denilerek not düşülmüş ancak alıcı yani benim haberim yok.

- Tüketici 18: Tüm şubeler telefonu açarken VV şubesi telefon kullanmıyor anlaşılan veya çalıp meşgule almaktadır. Çağrı merkezinde şikayet kaydı oluşturmama rağmen geri dönüşte olmadı. Şube marka değerini düşürmektedir. Ne yapalım kargo firması nereye isterse oradan biz mi teslim alalım?

- Tüketici 19: 05******85 numaralı gönderdiğim kargo 13.4.2021 19:03 itibariyle alıcıya ulaştığı yazıyor ama alıcı, kargoyu almadıklarını söylüyor. Buna kanıt olması açısından benden J Kargo UU şubesinden ilgili kargo takip numarasına dair teslim nüshası istediler. Bunun için arıyorum fakat sistemde kayıtlı olan 0549 **** 70-0549**** 71 telefonları hiçbir şekilde şube tarafından cevap verilemiyor bu yüzden teslim nüshasını talep edemiyorum. Teslim nüshası almam lazım, bunun için müşteri hizmetleri de siz şubeyle görüşmeden bir şey yapamayız dediler. Alıcı firmaya tes- 
lim edilmemişse bu kargo nerede? Neden teslim edilmeyen kargoyu teslim düşüyorsunuz?

- Tüketici 20: K Kargo şirketi, tarafıma adrese teslim olarak gönderilmiş olan kargomun hangi teslim şubesine gitmesi gerektiğini bilmemektedir........ Sonuç: Kargo şirketi, tarafıma adrese teslim olarak gönderilmiş ve ücreti ödenmiş olan taşıma hizmetini yerine getirmemiş, sorun müşterinin özel gayreti ile çözülmüştür. K Kargo şirketi bu çözüm için hiçbir şey yapmamış, konu ile ilgili olarak çalışanlarını dahi bilgilendirmemiş, daha da önemlisi müşterisine yaşattığı rahatsızlık nedeniyle herhangi bir özür dileme nezaketini dahi göstermekten aciz bir kuruluş olduğunu ortaya koymuştur. K Kargo, gerek hizmet anlayışı ve örgütlenme tarzı, gerek müşteri ilişkileri bakımından gerçek bir facia, benim gibi internet alışverişindeki satıcı tercihi nedeniyle mecburen maruz kalınmadığı sürece uzak durulması, tercih edilmemesi gereken bir kuruluştur.

- Tüketici 21: Cumartesi ÜÜ şubeye gelen ürün için, pazartesi L Kargo tarafından evde olmadığım için ürünün şubeye geri döndüğü ve 3 is günü içinde almamı söyledikleri bir mesaj geldi. Hemen şubeye gidip ürünü almak istedim fakat ürünün geri gittiği söylendi. Gönderici firmayı aradığımda böyle bir şeyin mümkün olmadığını sorunun L Kargo'dan kaynaklandığını belirttiler. .........3 is günü dolmadan gittiğim halde ürünümün geri gönderilmesi ve son olarak sağlık problemimden dolayı evden çıkmadığım halde evde olmadığım söylenip beni şubeye boşu boşuna gönderen L firmasından şikayetçiyim. Böyle ciddiyetsiz bir is yapilmaz...

\subsection{Duygusal Sinizm}

Duygusal boyutun bileşenleri, tüketicilerin işletme, ürün ya da markaya yönelik geliştirdikleri saygısızlık, öfke, endişe, sıkıntı ve utanç gibi güçlü duygusal tepkilerden meydana gelmektedir (Abraham, 2000: 282). Bu duygularla, bireyler işletmeye karşı küçümseme ve kızgınlık duygusu ya da örgütü düşündüklerinde acl, tiksinti hatta utanç gibi olumsuz duygular hissedebilmektedirler (Dean vd., 1998: 349; Beğenirbaş ve Turgut, 2014: 231). İronik olarak, sinikler işletmeleri kendi standartlarına dayanarak yargılayıp kusurlu bulduklarından dolayı kendilerinin işletmeye olan üstünlüklerinden bahseder ve bundan da gizli bir zevk alırlar. Bu yüzden siniklerin işletme hakkında sadece birtakım inançları bulunmadığı aynı zamanda bu inançlarla ilgili birtakım duygular da yaşadıkları da görülebilir (Dean vd., 1998: 349; Erdoğan ve Bedük, 2013: 30).

Web şikayet sitesinden seçilen metinler arasından duygusal boyutla ilgili olanlar şunlardır:
- Tüketici 22: $\mathrm{S}^{* * * * * * 35}$ numaralı siparişim internet alışveriş sitesinden, akü şarj cihazı aldım. M Kargo, kargomu başka birine vermiş, şimdi çözüm bekliyorum. Fakat M Kargo çalışanları bu olayın çözümü konusunda yardımcı olmuyorlar. Benim kargomu benim haberim olmadan nasıl başka birine verirler, burda bir şüphe var.

- Tüketici 23: İki tane ürün aldım sipariş bölümünde ürünler yola çıktı yazıyor. 2 hafta oldu halen ürünler gelmedi. Neden bu kadar geç geliyor ürünler elime geçeceğinden şüpheliyim. Bu siteden alışverişinden hiç memnun kalmadım. Şikayetçiyim... Ürünler şu an nerede hiç belli değil ...

- Tüketici 24: 13 Kasım 2020' de verdiğim ürün bugün 3 Aralık hatta 4 Aralık 2020 oluyor hala ortada yok mağaza kapandığı için kişiye ulaşamiyoruz bekleyin diyorlar. Benim hediye olarak aldığım bu doğum günü hediyesini veremedim mahcup oldum bu bir, mağdur ettiniz iadeye düşürdünüz bilgi vermediniz mağaza kapalı param ortada yok ürün kargo bilgisi yok bu iki, üçüncüsü de kartımın vadesi geçti kredi kartımı ödemeyi bana yapmadığınız için ödeme yapamadığımdan dolayı yatıramadım ve sizin yüzünüzden faiz işliyor hesabıma yani kısacası çok ağır bir şekilde mağdurum internet satış sitesi asistanda hep aynı otomatik mesajları yazıyorsunuz. Lütfen artık ücretimi paramı iade edin çünkü faiz işledikçe ben zarara uğruyorum tüm yazışmalarımda dijital ortamda kayıt altına alındı mahkeme için evraklarımı ve Tüketici Hakları için gerekli belgelerimi hazırladım bana vaat ettiğiniz ücreti yatırma tarihiniz 23 Kasım 2020 Pazartesi başlangıcı içinde 2-10 gün idi yarın cuma ve aralığa girdik eğer işlemlerim hızlanmaz ise pazartesi ya da salı tüm evrakları ve dokümanları sunacağım heyete ve avukata. Sizden bilgi ve çözüm istiyorum acilen paramı istiyorum faiz kredi kartıma işliyor ve zarardayım, acil çözüm istiyorum.

- Tüketici 25: Bir günde teslim vaktindeki $\mathrm{N}$ adlı kargo firması aldığım ürünlerimi 4 gündür hala teslim etmedi ürün dağıtıma hazırlanıyor yazıyor yürüyerek getirse kurye ürün çoktan gelmişti ayıp bir şey madem hızlı teslimat yapamıyorsunuz neden 1 günde teslim edilmeyi vaat ediyorsunuz. Sorumsuz firma ulaşabileceğiniz bir no yok.

- Tüketici 26: O Kargo şirketinin PP şubesi kadar berbat bir yer yok. Kargo şubesine 1 km uzaklıktayız, 4 gündür kargom gelmiyor. Arayıp ulaşabileceğimiz bir yer değil. İlgi yok takip yok hizmet yok. Türkiye'nin en kötü şubesi olabilir. Umarım yıl bitmeden kargom elime ulaşır.

- $\quad$ Tüketici 27: ÖÖ şubesindeki kargom için arayıp 
evde olmayacağımı kargomun komşuya veya güvenliğe iletilmesini ya da şubeden kendim alacağımı bildirmek için aradım. Şubeye ulaşmak mümkün değil telefonu açıp kapatıyorlar. Merkeze bağlanıyorum şubeleri arayamazlarmış o zaman merkez neden var? Şube telefonu için başka başka numaralar verip ya dalga geçiyorlar ya da oyalıyorlar. Merkez talebimi alacağına bildiğim şeyleri söylüyor. İnsana biraz saygı duysunlar. Bir daha Ö Kargo'yu asla kullanmayacağım.

Bilişsel sinizm, davranışsal sinizm ve duygusal sinizm ile ilgili şikâyet metinleri ile ilgili Atlas.ti nitel analiz programı aracılığı ile oluşturulan network analizi Şekil 1'dedir. Şekilde mesajlarla ilgili olarak oluşturulan kodlar ve temalar arasındaki ilişkiler de gösterilmektedir. Bu şekil, analize dahil edilen sinik tüketicilerin davranışını ortaya koymaktadır.

\section{SONUÇ VE ÖNERILER}

Günümüzün rekabet şartlarında pazardaki payı yüksek olan işletme ayakta kalmaktadır. İşletmenin pazar payının yüksek olması, sadık müşteri sayısına bağlıdır. Sadık müşteriler, memnun oldukları sürece işletme ürünlerini ya da markalarını tercih ederler. Bu müşteriler aynı zamanda mevcut müşteri olarak işletmenin aynı veya farklı ürünlerinden daha fazla satın alırlar. Etrafındaki insanlara bu ürünleri önerirler. Ancak işletmelerin tüm çabalarına rağmen beklentileri karşılanmayan, olumsuzluk ya da sorun yaşayanlar olacaktır. Eğer bu negatif durum tekrarlanırsa tüketiciler tutumlarını pekiştirmektedirler. Özellikle son yıllarda tüketicilerin bilinç düzeyinin artması, inter- net vb. gibi mecralarla araştırma yapmasının kolaylaşması, tüketici hakları ile ilgili yasalarının çıkması, tüketiciler arasındaki iletişim artması gibi sebeplerle tüketicilerin beklentileri artmıştır. Buna işletmelerin müşteriye her zamankinden daha fazla değer vermeleri eklendiğinde bu beklentiler daha da arttırmıştır. Buna paralel olarak tüketicilerin memnuniyetsizliği artmaktadır. Bu çalışmada tüketici tatminsizliğinin bir çeşidi olarak ortaya çıkan tüketici sinizm konu edilmiştir.

Tüketicinin işletmeye karşı takındığı olumsuz davranışlar tüketici sinizm olarak tanımlanmaktadır. Bu davranışların ortaya çıkma nedeni, işletmelerin tüketicilere zarar verecek gizli niyetlerinin olmasıdır. Sinik tüketiciler, işletmelerin kendi menfaatleri için hareket ettiklerine inandıkları için işletmelere güven duymazlar, kandırıldıklarını düşünürler. Sadece kendileri ya da yakın çevrelerine değil ulaşabildikleri herkese sinik duygularını aktarırlar. Bu nedenle sinik tüketicilerin davranışını belirlemek önemlidir. Bu amaçla bu çalışmada nitel araştırma yöntemlerinden netnografya analizi ile sinik tüketicilerin davranışı ortaya konulmaya çalışılmıştır.

Netnografya analizi yapılırken tüketicilerin sinik duygularını ifade ettikleri bir web müşteri şikâyet sitesinin tüketicilerinin mesajları seçilmiştir. Bu site, katılımsız gözlemci olarak beş ay takip edilmiştir. Veriler, arşivsel veri olarak toplanmıştır. Veriler incelendiğinde sinik tüketici davranışı üç tema altında toplanmıştır. Literatür incelendiğinde araştırma bulgularının Chylinski ve Chu (2010) ifade ettikleri tüketici sinizm ile ilgili boyutlar ile kısmen örtüştüğü görülmüştür. Yine

Şekil 1. Network Analizi (Araştırmacı tarafından oluşturulmuştur)

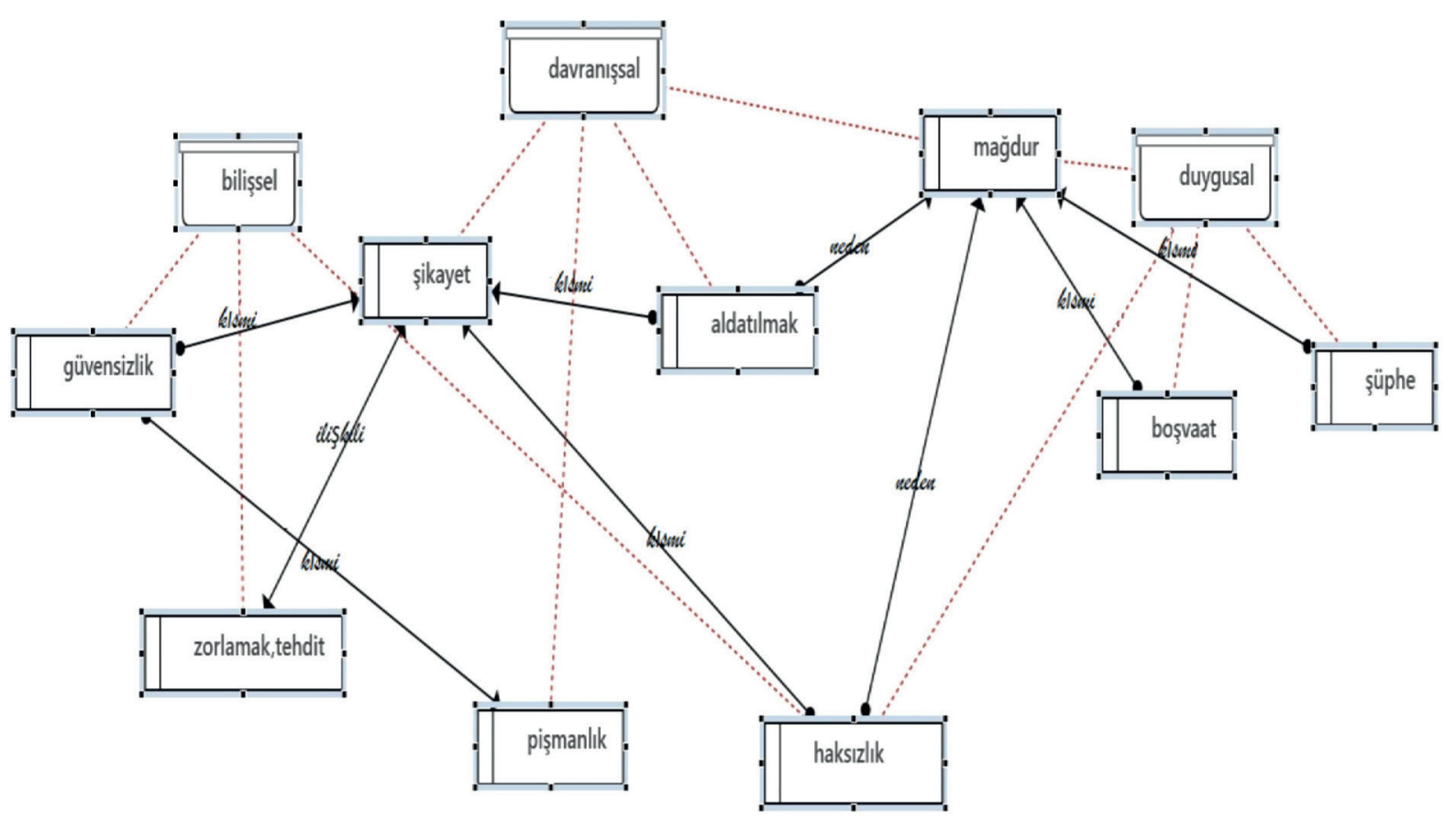


örgütsel sinizmde bu temalar Dean vd. (1998) tarafından örgütsel sinizm boyutları olarak kavramlaştırılmıştır. Araştırma bulguları, örgütsel sinizm ile ilgili geliştirilen sinizm çeşitlerinin tüketici sinizm için de geçerli olduğu görülmüştür. Araştırma sonucunda tüketicilerin sinik tutumlarını bilişsel sinizm, davranışsal sinizm ve duygusal sinizm olarak adlandırılmıştır.

Bilişsel sinizm, işletmelerin tüketicileri kandırdıkları, kendi menfaatlerini ön planda tuttukları ile ilgili geliştirilen tüketici davranışıdır. Şikâyet metinlerine bakıldığında tüketicilerin bilişsel sinizmi güvensizlik, zorlamak (tehdit) ve haksızlık şeklinde ifade ettikleri görülmektedir. Chylinsky ve Chu (2010), yaptıklar1 çalışmalarında bilişsel boyutu şüphe, güvensizlik, kuşku ve itimatsızlık ile ifade etmişlerdi. Bu araştırmada bulunan güvensizlik durumuyla örtüşmektedir. Yapılan araştırmada güvensizlik, zorlamak (tehdit) ve haksızlık durumlarıyla karşılaşan tüketicilerin işletmeye karşı bilişsel sinizm oluşturdukları söylenebilir. Davranışsal sinizm, işletmenin ürünü, markası ya da kendisi ile ilgili bir eylemde bulunmasıdır. Yapilan netnografya analizi sonucunda sinik tüketiciler, şikâyet, pişmanlık, aldatılmak ve mağdur olma durumlarından bahsetmektedirler. Bu tüketicilerin sözel söylemlerinden ziyade bunu davranışa çevirdikleri söylenebilir. Metinler dikkate alındığında bu tüketicilerin daha kötümser oldukları aslında şikâyet etmekle birlikte olumlu sonuçlar beklemedikleri de söylenebilir. Chylinsky ve Chu (2010) araştırmaların sonucunda davranışsal sinizm boyutunda direniş ve düşmanlık olduğunu elde etmişlerdir. Araştırma sonucunda bulunan durumlar incelendiğinde kötümserlik içerdiği görülebilir. Duygusal sinizm ise tüketicilerin işletmelere karşı gösterdikleri duygusal tepkileri ifade etmektedir. Araştırma sonucunda bu duygusal durumlar, şüphe, boş vaat, haksızlık ve mağdur olma olarak bulgulanmıştır. Şikâyet metinlerinde sinik tüketicilerin işletme ile ilgili geliştirdikleri inançlarla ilgili duygular yaşadıkları görülmüştür. Yine Chylinsky ve Chu (2010) tarafından yapılan araştırma sonuçlarına bakıldığında duygusal boyut ile ilgili yabancılaşma ve tatminsizlikten bahsedilebilir. Yapılan araştırmada şüphe durumu bilişsel sinizm olarak ele alınmıştır. Bu, Chylinsky ve Chu (2010)'nin araştırmaları ile farklıdır. Ancak boş vaat, haksızlık ve mağdur olma tatminsizlik ve yabancılaşmayı ortaya çıkartan durumlar şeklinde yorumlanabilir. Araştırma sonucunda dikkat çeken bir konu, farklı durumların ortak sinik tüketici davranışına dâhil olmasıdır. Mesela, haksızlık hem bilişsel sinizm hem de duygusal sinizme dâhil olmaktadır. Çünkü tüketici her iki sinizmi de birlikte yaşayarak hem bilişsel olarak hem de duygusal davranışlar göstermektedirler.

Aslında araştırma esnasında sinik tüketicilerin olumsuzluğa neden olan konunun ortadan kaldırılması, kendilerinin önemsenmesini ve ilgi gösterilmesini istemektedirler. Tüketici ile doğru iletişim kurulursa ve sinik davranışa neden olan sorunlar çözülürse tüketiciyi olumluya çevirmek mümkündür. Özellikle müşteri ilişkileri açısından bu önemlidir. Bu açıdan araştırma sonucunda bulunan sonuçlar işletmeler aç1sından oldukça önemlidir. Sinik tüketici davranışına göre davranan işletmeler, bu müşterileri kazanacaklardir.

$\mathrm{Bu}$ araştırma nitel bir çalışmadır. Genelleştirilmesi mümkün değildir. Ancak sonuçlarının literatüre katkı sağladığ 1 düşünülmektedir. Özellikle bu konuda çalışma yapacaklar için keşfedici bir çalışmadır.

\section{KAYNAKÇA}

ABRAHAM, R. (2000). Organizational Cynicism: Bases and Consequences, Genetic, Social, and General Psychology Monographs. 126 (3), 269-292.

AKÇAY, G. (2021). Tüketici Sinizminin Öncülleri ve Sonuçları: Hizmet Sektörü Üzerinde Bir Araştırma. (Yayınlanmamış Doktora Tezi). Bursa Uludağ Üniversitesi Sosyal Bilimler Enstitüsü, İşletme Anabilim Dalı Üretim Yönetimi ve Pazarlama Bilim Dalı, Bursa.

AKTURAN, U. (2009). A review of Cyber Ethnographic Research: A Research Technique To Analyze Virtual Consumer Communities, Boğaziçi Journal, 23(1-2), 1-18.

AMEZCUA, B. \& QUINTANILLA, C. (2016). When eWOM Becomes Cynical, International Journal of Consumer Studies, 40(3), 290-298.

ANDERSSON, L. M. (1996). Employee cynicism: An Examination Using a Contract Violation Framework, Human Relations, 49 (11), 1395-1418

ARSLAN, A. \& ŞiMŞ̧EK, G. (2018). Örgütsel Sinizm ve İş Tatmini Arasındaki İlişkiler: Aydın Turist Rehberleri Odası'na Kayıtlı Olan Profesyonel Turist Rehberleri Örneği, Journal of Travel and Tourism Research, 13, 115-134.

ARSLAN, E.T. (2012). Süleyman Demirel Üniversitesi İktisadi ve İdari Bilimler Fakültesi Akademik Personelinin Genel ve Örgütsel Sinizm Düzeyi, Doğuş Üniversitesi Dergisi, 13(1), 12-27.

ATILGAN, K. Ö. , İNCE, T. \& YILMAZ, S. (2017). Tüketicilerin Satın Alma Niyetleri ve Boykota Yönelik Tutumlarının Tüketici Sinizmi, Fiyat Şeffaflığı ve Fiyat Adaleti Bağlamında İncelenmesi, Çukurova Üniversitesi Sosyal Bilimler Enstitüsü Dergisi, 26(3), 34-44.

BEAVEN, Z. \& CHANTAL L. (2007). Never Let Me Down Again': Loyal Customer Attitudes Towards Ticket Distribution Channels for Live Music Events: A Netnographic Exploration of The US Leg of The Depeche Mode 2005-2006 World Tour, Managing Leisure 12(2-3), 120-142.

BEĞENIRBAŞ, M. \& TURGUT, E. (2014). İş Yaşamında Çalışan- 
ların Duygusal Emeklerinin Örgütsel Sinizme Etkileri: Bankacılık Sektöründe Bir Araştırma, Çankırı Karatekin Üniversitesi İ̈BF Dergisi, 4(2), 223-246.

BERDYSHEVA, E. \& ROMANOVA, R. (2017). Rethinking Prices During An Economic Crisis: Calculation As A New Mode of Consumer Behaviour in Russia, International Journal of Consumer Studies, 41, 397-403.

BERTILSSON, J. (2015). The Cynicism of Consumer Morality. Consumption Markets \& Culture, 18(5), 447-467.

BRANDES, P., DHARWADKAR, R. \& Dean, J. (1999). Organisational Cynicism, Academy of Management Review. 23(2), 341-352.

BRANDES, P. \& DAS, D. (2006). Locating Behaviour Cynicism at Work: Construct Issues and Performance Implications: 233-266 içinde PERREWE, P. L. \& GANSTER, D. C. (Eds.). Employee Health, Coping and Methodologies. New York: JAI Press.

BRANDES, P., DHARWADKAR, R. \& DEAN, J. W. (1999). Does Organizational Cynicism Matter? Employee and Supervisor Perspectives on Work Outcomes, Eastern Academy of Management Proceedings: 150-153.

BRAUN, V. \& CLARKE, V. (2006). Using Thematic Analysis in Psychology. Qualitative research in psychology, 3(2), 77-101.

CHALOUPKA, W. (1999). Everybody Knows: Cynicism in Ameri$c a$, Minneapolis: University of Minnesota Press.

CHERRIER, H. \& MURRAY, J. (2004). The Sociology of Consumption: The Hidden Facet of Marketing, Journal of Marketing Management, 20(5), 509-524.

CHYLINSKI, M. \& CHU, A. (2010). Consumer Cynicism: Antecedents and Consequences, European Journal of Marketing, 44(6), 796-837.

COSTA, P. T., ZONDERMAN, A. B., MC CRAE, R. R., \& WILLIAMS, R. B. (1983). Content and Comprehensiveness in the MMPI: An Item Factor Analysis in A Normal Adult Sample, Journal of Personality and Social Psychology, 48 (4), 925-933.

DEAN J. W. Jr., BRANDES P. \& DHARWADKAR R. (1998). Organizational Cynicism, Academy of Management Review, 23(2), 341-352.

DOLEN, W. M., DE CREMER, D. \& DE RUYTER, K. (2012). 'Consumer Cynicism Toward Collective Buying: The Interplay of Others' Outcomes, Social Value Orientation, and Mood, Psychology \& Marketing, 29(5), 306-321.

DUDLEY D. R. (1937). A History of Cynicsm, London: Methuen and Co.

ERCAN, A. \& KAZANÇOĞLU, İ. (2019). Örgütsel Sinizm: Satış Personeli Üzerine Nitel Bir Araştırma, Yönetim ve Ekonomi Araşttrmaları Dergisi, 17(1), 261-280.

ERDOĞAN, P. \& BEDÜK, A. (2013). Örgütsel Sinizm İle Örgütsel Vatandaşlık Davranışı Arasındaki İlişki: Sağlık Sektöründe Bir Araştırma, Selçuk Üniversitesi Sosyal ve Teknik Araştırmalar Dergisi, 1(6), 17-36.

KRETZ, G. (2010). Pixelize Me!: a Semiotic Approach of Self-Digitalization in Fashion Blogs", içinde NA - Advances in Consumer
Research, 37,. CAMPBELL, M.C., INMAN, J. \& PIETERS R.(eds) Duluth, MN : Association for Consumer Research: 393-399.

GÖKTAȘ, B. (2019). Tüketici Sinizmi Kavramı ve Ağızdan Ağıza Pazarlama Eylemlerinin Sinik Tüketici Davranışlarına Etkisi Konusunda Bir Uygulama, OPUS Uluslararası Toplum Araştırmaları Dergisi 13(19), 1650-1692.

GÜVEN, E. (2016). Tüketimde Sinik Tutum: Tüketici Sinizminin Sebep ve Sonuçları, İsletme Araştırmaları Dergisi 8(2), 152-174.

HELM, A.E., MOULARD, J.G. \& RICHINS, M. (2015). Consumer Cynicism: Developing a Scale to Measure Underlying Attitudes Influencing Marketplace Shaping and Withdrawal Behaviours, International Journal of Consumer Studies, 39(5), 515-524.

INDIBARA, I. \& SANJEEV, V. (2020). Cynical consumer: how social cynicism impacts consumer attitude, Journal of Consumer Marketing, 38(1), 78-90.

KANTER, D, L. \& Mirvis, P. H., (1989). The cynical Americans; Living and working in an age of discontent and disillusion. San Francisco, CA: Jossey-Bass Inc.

KARACAOĞLU, K. \& İNCE, F. (2012). Brandes, Dharwadkar ve Dean`in (1999) Örgütsel Sinizm Ölçeği Türkçe Formunun Geçerlilik ve Güvenilirlik Calışması: Kayseri Organize Sanayi Bölgesi Örneği, Business and Economics Research Journal, 3(3), $77-92$.

KENNEDY, W. J. (2017). Antisthenes' Literary Fragments: Edited with Introduction, Translations, and Commentary. $(\mathrm{PhD})$. University of Sydney Faculty of Arts, Sydney.

KETRON, S. (2016). Consumer Cynicism and Perceived Deception in Vanity Si-Zing: The Moderating Role of Retailer (Dis)honesty, Journal of Retailing and Consumer Services, 33, 33-42.

KOÇ, E. (2013). Tüketici Davranışı ve Pazarlama Stratejileri Global ve Yerel Yaklaşım, Beşinci baskı, Ankara: Seçkin Yayıncılık.

KOZINETS, R.V. (2010). Netnography: Doing Ethnographic Research Online, First edition, London: Sage Publications.

KOZINETS, R. V. (2002). The Field Behind The Screen: Using Netnography for Marketing Research in Online Communities, Journal of Marketing Research, 39(1), 61-72. doi:10.1509/ jmkr.39.1.61.18935

KOZINETS, R.V. (2010). Netnografi: Pazarlamacının Gizli Silahı Sosyal Medya Anlayışı İnovasyonu Nasıl Harekete Geçirir, 2010, http://kozinets/net/wp-content/uploads/2012/01/netnographyturkish.pdf [Erişim Tarihi: 12/01/2021]

KOZINETS, R.W. (2006) Click to Connect: Netnography and Tribal Advertising. Journal of Advertising Research, 46: 279-288. http://dx.doi.org/10.2501/S0021849906060338 [Erişim Tarihi: $14 / 02 / 2021]$

LACZNIAK, R. N., DECARLO, T. E. \& RAMASWAMI, S. N. (2001). Consumers' Responses to Negative Word-of-Mouth Communication: An Attribution Theory Perspective, Journal of Consumer Psychology, 11(1), 57-73.

LANGER, R. \& BECKMAN, S. C. (2005). Sensitive Research Topics: Netnography Revisited. Qualitative Market Research, 8 (2), 189-203. 
LAURSEN, J. C., (2009). Cynicism Then and Now, Iris: European Journal of Philosophy and Public Debate, 1(2), 469-482.

LUCK, G. (2011). Köpeklerin Bilgeliği: Antikçă̆ Kiniklerinden Metinler, (çev. Oğuz Özügül), 1. baskı, İstanbul: Say Yayınları.

MACLAREN, P. \& CATTERALL, M. (2002). Researching The Social Web: Marketing Information from Virtual Communities. Marketing Intelligence and Planning, 20(6), 319-326.

MANTERE, S. \& MARTINSUO, M. (2001). Adopting and Questioning Strategy: Exploring the Roles of Cynicism and Dissent, European Group for Organisation Studies Colloquium, (July 5-7), $1-25$.

MAZELLA, D. (2007). The Making of Modern Cynicism, 1st ed., Charlottesville: University of Virginia Press.

MIKKONEN, I., MOISANDER, J. \& FIRAT, A.F. (2011). Cynical Identity Projects as Consumer Resistance-The Scrooge as a Social Critic?, Consumption, Markets and Culture, 14(1), 99-116.

NALETELICH, K. \& KETRON, S. (2017). Humanizing Conservation: How Anthropo-Morphism Overcomes Cynicism, AMA Summer Educators' Conference Proceedings, 28, 11-12.

ODOU, P. \& PECHPEYROU, P. (2011). Consumer Cynicism: From Resistance to Anticonsumption in a Disenchanted World?, European Journal of Marketing, 45(11/12), 1799-1808.

OGUNFOWORA, B., STACKHOUSE, M. \& OH, W.Y. (2015). CSR Motive Attributions: The Roles of Executive Leadership Ethics and Consumer Cynicism. Academy of Management Annual Meeting Proceedings, (1), 1306-1311.

ROBERTS, H. G. A. (2006). Dogs' Tales: Representations of Ancient Cynicism in French Renaissance texts, Amsterdam: Rodopi

STANLEY, D. J. (2005). Employee Cynicism and Resistance to Organizational Change, Journal of Business and Psychology, 19(4), 429-458.

TOKGÖZ, N. \& YILMAZ, H. (2008). Örgütsel Sinisizm: Eskişehir ve Alanya'daki Otel İşletmelerinde Bir Uygulama, Anadolu Üniversitesi Sosyal Bilimler Fakültesi Dergisi, 8(2), 283-305. 